\title{
Middle Ear Squamous Cell Carcinoma
}

National Cancer Institute

\section{Source}

National Cancer Institute. Middle Ear Squamous Cell Carcinoma. NCI Thesaurus. Code C6086.

A rare squamous cell carcinoma that arises from the middle ear. 